\title{
The chemical industry, oil
}

\author{
Ali Moeinpour \\ Chemical Industries, Eram University, Shiraz, Iran \\ meysamlft@gmail.com \\ Zahra Sayyahmeimandi \\ Management, Zand University, Shiraz, Iran
}

\begin{abstract}
Natural oil and gas (petroleum) are found below the Earth's surface and are highly prized as sources of both fuel and as starting materials for many commercial products, including most plastics. Petroleum engineering is the application of chemistry, physics, math, geology, and engineering principles to discover a cost-effective way to identify promising areas for exploration, access this natural resource, and refine it into desirable products. Chemists in the oil and petroleum industry work with crude oil and the products derived from it. The industry is divided into both "upstream" and "downstream" parts, depending on how far away from the well the work is. The upstream activities include exploration and production and the downstream activities include refining and marketing comprise the petroleum industry. This industry needs chemical engineers, organic, analytical, inorganic, physical chemists, biochemists, and geochemists, as well as experts in tracer chemistry, informatics, and more. Biochemistry is important in the production of oil because bacteria change the quality of oil over time, interfering with production and causing downstream corrosion problems and toxic hazards, for example. Inorganic chemists, organic chemists, analytical chemists, and chemical engineers all play a role in catalyst science, technology, and development, which is crucial for the petroleum and petrochemical industries.
\end{abstract}

Keywords: Industry, Oil, Chemicals.

\section{Introduction}

The petroleum industry, also known as the oil industry or the oil patch, includes the global processes of exploration, extraction, refining, transporting (often by oil tankers and pipelines), and marketing of petroleum products. The largest volume products of the industry are fuel oil and gasoline (petrol). Petroleum (oil) is also the raw material for many chemical products, including pharmaceuticals, solvents, fertilizers, pesticides, synthetic fragrances, and plastics. The industry is usually divided into three major components: upstream, midstream and downstream. Midstream operations are often included in the downstream category.Petroleum is vital to many industries, and is of importance to the maintenance of industrial civilization in its current configuration, and thus is a critical concern for many nations. Oil accounts for a large percentage of the world's energy consumption, ranging from a low of $32 \%$ for Europe and Asia, to a high of 53\% for the Middle East.Other geographic regions' consumption patterns are as follows: South and Central America (44\%), Africa (41\%), and North America (40\%). The world consumes 30 billion barrels $\left(4.8 \mathrm{~km}^{3}\right)$ of oil per year, with developed nations being the largest consumers. The United States consumed $25 \%$ of the oil produced in 2007 . The production, distribution, refining, and retailing of petroleum taken as a whole represents the world's largest industry in terms of dollar value.

While many of the products from the industry, such as detergents, soaps and perfumes, are purchased directly by the consumer others are used as intermediates to make other products, For example, in Europe, $70 \%$ of chemicals manufactured are used to make products by other industries including other branches of the chemical industry itself. The industry uses a wide range of raw materials, from air and minerals to oil. 
What does the chemical industry produce?

The products of the chemical industry can be divided into three categories:

\section{Modern history}

Imperial Russia produced 3,500 tons of oil in 1825 and doubled its output by mid-century. After oil drilling began in what is now Azerbaijan in 1846 in Baku, two large pipelines were built in the Russian Empire: the $833 \mathrm{~km}$ long pipeline to transport oil from the Caspian to the Black Sea port of Batum (Baku-Batum pipeline), completed in 1906, and the $162 \mathrm{~km}$ long pipeline to carry oil from Chechnya to the Caspian. Batum is renamed to Batumi in 1936.At the turn of the 20th century, Imperial Russia's output of oil, almost entirely from the Apsheron Peninsula, accounted for half of the world's production and dominated international markets. Nearly 200 small refineries operated in the suburbs of Baku by 1884. As a side effect of these early developments, the Apsheron Peninsula emerged as the world's "oldest legacy of oil pollution and environmental negligence." In 1846, Baku the first ever well drilled with percussion tools to a depth of 21 meters for oil exploration. In 1878, Ludvig Nobel and his Branobel company "revolutionized oil transport" by commissioning the first oil tanker and launching it on the Caspian Sea. Samuel Kier established America's first oil refinery in Pittsburgh on Seventh avenue near Grant Street, in 1853. One of the first modern oil refineries were built by IgnacyŁukasiewicz near Jasło (then in the dependent Kingdom of Galicia and Lodomeria in Central European Galicia), Poland in 1854-56. These were initially small, as demand for refined fuel was limited. The refined products were used in artificial asphalt, machine oil and lubricants, in addition to Lukasiewicz's kerosene lamp. As kerosene lamps gained popularity, the refining industry grew in the area.

The first commercial oil well in Canada became operational in 1858 at Oil Springs, Ontario (then Canada West). Businessman James Miller Williams dug several wells between 1855 and 1858 before discovering a rich reserve of oil four metres below ground. Williams extracted 1.5 million litres of crude oil by 1860 , refining much of it into kerosene lamp oil. Some historians challenge Canada's claim to North America's first oil field, arguing that Pennsylvania's famous Drake Well was the continent's first. But there is evidence to support Williams, not least of which is that the Drake well did not come into production until August 28, 1859. The controversial point might be that Williams found oil above bedrock while Edwin Drake's well located oil within a bedrock reservoir. The discovery at Oil Springs touched off an oil boom which brought hundreds of speculators and workers to the area. Canada's first gusher (flowing well) erupted on January 16, 1862, when local oil man John Shaw struck oil at 158 feet $(48 \mathrm{~m})$. For a week the oil gushed unchecked at levels reported as high as 3,000 barrels per day.

The first modern oil drilling in the United States began in West Virginia and Pennsylvania in the 1850s. Edwin Drake's 1859 well near Titusville, Pennsylvania, is typically considered the first true modern oil well, and touched off a major boom. In the first quarter of the 20th century, the United States overtook Russia as the world's largest oil producer. By the 1920s, oil fields had been established in many countries including Canada, Poland, Sweden, Ukraine, the United States, Peru and Venezuela. The first successful oil tanker, the Zoroaster, was built in 1878 in Sweden, designed by Ludvig Nobel. It operated from Baku to Astrakhan. A number of new tanker designs were developed in the 1880 s.

In the early 1930s the Texas Company developed the first mobile steel barges for drilling in the brackish coastal areas of the Gulf of Mexico. In 1937 Pure Oil Company (now part of Chevron Corporation) and its partner Superior Oil Company (now part of ExxonMobil Corporation) used a fixed platform to develop a field in 14 feet $(4.3 \mathrm{~m})$ of water, one mile $(1.6 \mathrm{~km})$ offshore of Calcasieu Parish, Louisiana. In early 1947 Superior Oil erected a drilling/production oil platform in $20 \mathrm{ft}(6.1 \mathrm{~m})$ of water some 18 miles[vague] off Vermilion Parish, Louisiana. It was Kerr-McGee Oil Industries (now Anadarko Petroleum Corporation), as operator for partners Phillips Petroleum (ConocoPhillips) and Stanolind Oil \& Gas (BP), that completed its historic Ship Shoal Block 32 
well in November 1947, months before Superior actually drilled a discovery from their Vermilion platform farther offshore. In any case, that made Kerr-McGee's Gulf of Mexico well, Kermac No. 16, the first oil discovery drilled out of sight of land. Forty-four Gulf of Mexico exploratory wells discovered 11 oil and natural gas fields by the end of 1949. During World War II (1939-1945) control of oil supply from Baku and Middle East played a huge role in the events of the war and the ultimate victory of the allies. Cutting off the oil supply considerably weakened Japan in the latter part of the war. After World War II ended, the countries of the Middle East took the lead in oil production from the United States. Important developments since World War II include deep-water drilling, the introduction of the Drillship, and the growth of a global shipping network for petroleum relying upon oil tankers and pipelines. In 1949, first offshore oil drilling at Oil Rocks (NeftDashlari) in the Caspian Sea off Azerbaijan eventually resulted in a city built on pylons. In the 1960s and 1970s, multi-governmental organizations of oil-producing nations OPEC and OAPEC played a major role in setting petroleum prices and policy. Oil spills and their cleanup have become an issue of increasing political, environmental, and economic importance.

\section{Basic chemicals, Speciality chemicals}

Several other categorisations are used but this one is simple and helpful in the context of this web site. Outputs range widely, with basic chemicals produced in huge quantities (millions of tonnes) and some speciality chemicals produced in modest kilogramme quantities but with very high value. As explained in the unit on Chemical Reactors, the choice of reactor is often goverened by the amount of chemical that is to be produced.

\section{Specialty Chemicals}

Leveraging on the country's strengths as a leading market player in other areas such as marine and offshore engineering, water treatment and lubricants, Singapore is well-positioned to further expand the chemical industry by focusing on high value-added specialty chemicals that serve these sectors. Additionally, specialty chemicals companies can leverage the close proximity from Singapore to their customers and the end-consumer, and respond with agility to the emerging needs of Asian consumers by innovating new applications.

Basic chemicals are divided into

chemicals derived from oil, known as petrochemicals

polymers

basic inorganics

The term 'petrochemical' can be misleading as the same chemicals are increasingly being derived from sources other than oil, such as coal and biomass. An example is methanol, commonly produced from oil and natural gas in the US and Europe but from coal in China. Another is ethene, derived from oil and gas in the US and Europe but increasingly from biomass in Brazil. Other examples are described in the units on this web site.

Basic chemicals, produced in large quantities, are mainly sold within the chemical industry and to other industries before becoming products for the general consumer. For example, ethanoic acid is sold on to make esters, much of which in turn is sold to make paints and at that point sold to the consumer. Huge quantities of ethene are transported as a gas by pipeline around Europe and sold to companies making poly(ethene) and other polymers. These are then sold on to manufacturers of plastic components before being bought by the actual consumer. Figure 3 shows a plant producing chemicals which it then immediately uses to manufacture other chemicals.

\section{References}

I. Derry, Thomas Kingston; Williams, Trevor I. (1993). A Short History of Technology: From the Earliest Times to A.D. 1900. New York: Dover. 
II. Kiefer, David M. (2001). "Sulfuric Acid: Pumping Up the Volume". American Chemical Society. Retrieved 2008-04-21.

III. "The Chemical Industries In The UK". American Chemical Society. Retrieved 2013-04-21.

IV. Aftalion, Fred (1991). A History of the International Chemical Industry. Philadelphia: University of Pennsylvania Press. pp. 11-13. ISBN 0-8122-1297-5.

V. Aftalion 1991, p. 104, Chandler 2004, p. 475

VI. "Electrolytic Production of Bromine - National Historic Chemical Landmark - American Chemical Society". American Chemical Society. Retrieved 2016-10-10.

VII. UK Patent office (1857). Patents for inventions. UK Patent office. p. 255.

VIII. Jeannifer Filly Sumayku, Unilever: Providing Enjoyable and Meaningful Life to Customers, The President Post, 22 March 2010

IX. Centi, Gabriele (January 2012). "Resources and energy efficiency :the winning strategy for chemical industry" (PDF). La Chimical'Industria. SocietàChimicaItaliana (1): 64-67. 